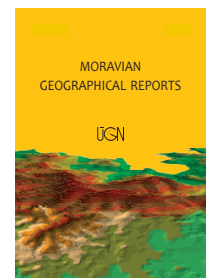

\title{
Retail sprawl in post-Soviet urban residential communities: Case studies of Saint-Petersburg and Vilnius
}

\author{
Konstantin AXENOV ${ }^{\text {a }}$, Dovilè KRUPICKAITE ${ }^{\text {b }}$, Kira MORACHEVSKAYA ${ }^{\text {a }}$, Andrey ZINOVYEV a
}

\begin{abstract}
Since the beginning of the 1990s, Soviet urban residential communities have experienced rapid inflows of new urban functions. In this research project, two post-Soviet urban areas - Vilnius and St. Petersburg - are examined to indicate contrasting development paths over the last 30 years. The term "retail sprawl" describes correctly one of the important processes which have reshaped the former socialist microdistricts. We used data from the years 1987-1989, the last years of the socialist economy, and 2016 for 36 comparable research areas. By 2016 the structure of these formerly monofunctional areas made them functionally very similar to that of the urban core, including them in the intra-urban circulation of goods and capital, redirecting flows and making the city centre's service burden much lighter. The results of the study provide a controversial contribution to the virtual discussion on universalism vs. uniqueness in post-socialist urban development. On the one hand, irrespective of contrasting "path-dependent" impacts, the structural results of retail development turned out to be generally identical in the studied cities at present, as well as in a prototypical North-American city 25 years ago. On the other hand, we found very pronounced differences compared to international patterns in morphological outcomes.
\end{abstract}

Keywords: post-socialist cities; microrayons; retail sprawl; street retail; Saint-Petersburg; Vilnius; Russia; Lithuania

Article history: Received 1 June 2018; Accepted 10 September 2018; Published 30 September 2018

\section{Introduction}

Describing shifts in non-residential land uses in a CentralEast European (CEE) post-socialist metropolis ${ }^{1}$, K. Stanilov (2007b, p. 78) outlines in his most extensive study, two major spatial trends:

1. CBD-forming, the concentration of upscale retail, offices, etc.; and

2. the de-concentration of commercial functions.

Like other researchers (for example, Couch et al., 2007) Stanilov considers the latter trend to be of primary importance for the development of the city's outskirts, claiming that "de-concentration of office, retail and industrial uses has had a stronger impact on the spatial structure of the CEE metropolitan areas than the concurrent processes of residential de-concentration" (Stanilov, 2007b, p. 78). If the trend related to CBD-forming in post-Soviet cities has been described in some detail (see for example, Rudolph, 2001), the process of the de-concentration of commercial functions clearly lacks academic attention. This lack might indicate a gap since, during the last decade, one could witness something of a boom-type development of commercial (primarily retail) functions in the vast areas of the formerly exclusively residential high-rise "sleeping quarters", erected during the socialist period. Such areas, which host the majority of the population in many post-Soviet urban centres, experienced rapid inflows of new urban functions primarily commercial - which not only interrupted their traditional monofunctionality but contributed to large-scale land-use and morphological shifts, a redirection of flows and reconfiguration of the metropolitan areas in general. This process is the main focus of the present research and we shall incorporate it into a much broader account of the urban sprawl phenomenon.

\footnotetext{
${ }^{a}$ St. Petersburg State University, Russia (*corresponding author: K. Axenov, e-mail: axenov@peterlink.ru)

${ }^{\mathrm{b}}$ Vilnius University, Lithuania
}

\footnotetext{
${ }^{1}$ We use several terms in order to characterise our research area in space and time. The term CEE is used to indicate the broader geographical context of our field of interest. Among some other areas, it covers many post-socialist European areas, including Russia. We will attribute the term 'post-socialist' to them in describing the period from the end of $1980 \mathrm{~s}-$ thus meaning by postsocialism purely a "spatio-temporal container" in the terms of Tuvikene (2016). The term 'post-Soviet' is prescribed here only to that part of the aforementioned CEE post-socialist territory which, before 1991, was an integral part of the USSR.
} 
Apart from these general trends, we shall address the following research questions:

- To what extent has the socialist microrayon principle in former microdistrict areas been affected by the development of retail land uses?

- How did this process contribute to the redistribution of functions within urban areas in general?

- Could these trends be treated as uniform over postSoviet space? and

- How do they fit into global trends of retail distribution within urban areas?

\section{Theoretical background}

\subsection{Retail sprawl implications for post-Soviet cities ${ }^{2}$}

The term "sprawl" has become popular not only in urban studies but also in public use for a long time. According to the Oxford English Dictionary, "sprawl" first appeared in print in this context in 1955, in an article in the London Times on 10 August, 1955: "London's great sprawl will inevitably engulf us sooner or later, no matter how many "green belts" are interposed in the meantime between the colossus and ourselves". Although a general understanding of the term "urban sprawl" is basically common, some variety in its use exists. While some exploit this term to define specific land use patterns (Couch et al., 2007), others apply it to socio-spatial shifts (Gu et al., 2015; Simion and Nistor, 2012). Since formal definitions of "urban sprawl" are quite numerous and vary in detail (for overviews, see for example: Bruegmann, 2005; Couch et al., 2007; Storper and Scott, 2016; Oueslati et al., 2015; Sarzynski et al., 2014), we tend to treat it rather as a general concept and shall outline attributes of it which are shared by many researchers. Thus, we understand urban sprawl as:

- A primarily centrifugal process of spatial expansion of certain urban functions to areas formerly not occupied by them (Couch et al., 2007);

- A process that covers peripheral (primarily but not exclusively suburban) zones of a city (European Environment Agency, 2006);

- A process that might be related to several urban functions: residential, commercial, etc.: such functions might expand relatively independently and not simultaneously (Nilsson et al., 2013);

- A process that withdraws urban functions which are highly or overly concentrated in the urban core and forms spatial patterns at the urban fringes, where these functions are distributed at much lower densities (Bruegmann, 2005); and

- A process which is market-driven and could hardly be planned or controlled in full - hence being selfgoverned and to a certain extent spontaneous (European Environment Agency, 2006).

Two aspects of the urban sprawl discourse are of greater importance for our research. First, the specificity of different types of urban sprawl that were made common by the usage of sub-concepts such as "residential sprawl", "retail sprawl" and even more specifically "industrial sprawl" (Couch et al., 2007; Nilsson et al., 2013), contextualise our approach.
It is exactly the pronounced phenomenon of retail sprawl among such others, in the spatial expansion of retail activity that is the focus of our research.

Second, in this research project, we apply the urban sprawl concept to former Soviet urban residential communities, also referred to in the literature as large housing estates (LHE) (van Kempen et al., 2005; Wassenberg, 2013; Szafranska, 2013), microdistricts or microrayons (SNIP, 1994; Meuser and Zadorin, 2016). We shall discuss this matter in more detail below.

Unlike in the West, microdistricts became the major morphological form of development in the CEE cities' fringes after World War II. Research by Couch et al. determined that in the 1990s commercial development had a more significant impact on the transformation of outer city areas than housing construction (Couch et al., 2007). Simion and Nistor indicated that after the fall of the socialist regime, "retail centres were one of the first elements of new urban evolution of the city, being after followed by residential or office buildings" (Simion and Nistor, 2012, pp. 79-89). Other authors, using the case of Leipzig, demonstrated that retail sprawl started before residential sprawl: immediately after German reunification in 1990, a number of investors came to the city, developing land and constructing new buildings to explore business opportunities and take advantage of the new market (Nilsson et al., 2013).

The first effects of the collapse of socialist regimes for urban systems were investigated by Musil (1992). Shops and services were identified as one of the four urban actors in changing the urban environment, along with industry, house-owners and private households. The retail revolution in post-socialist Central Europe has been described in detail in several publications (e.g. Tsenkova and NedovicBudic, 2006; Nagy, 2001; Pojani, 2011). Mostly they have investigated a remarkably rapid shift in retailing, in which hypermarkets approached half of the retail market share within one decade. These authors found that retailing led urban decentralisation with residential and job sprawl. Institutional obstacles to retail development were identified by Maksic (2016), who stated that land policy reform was crucially important for retail projects in postsocialist cities.

Thus, these previous studies mostly deal with retail sprawl in the suburbs, barely touching the "commercialisation" of "sleeping quarters" erected during the socialist period.

In this study, we distinguish retail sprawl from retail deconcentration or decentralisation. Retail de-concentration is normally measured by the shares of retail allocated to the core (city centre) and periphery (urban fringes). This share may grow, reflecting the concentration process, fall (de-concentration) or grow again (re-concentration), following Dawson and Lord (2013). While "concentrationde-concentration-re-concentration" should be treated as a two-directional process, sprawl by definition is a singledirectional one. According to our previous research, during the post-Soviet period spatial retail dynamics had in fact passed through the concentration (a growing share of the city centre), de-concentration (reduction in this share), and re-concentration (growing again) stages (Axenov et al., 2006, p. 158). At the same time, the density of retail functions in the housing areas (LHE) was constantly growing, making

\footnotetext{
${ }^{2}$ After Kent and Omar (2003), we assume that the retail industry consists of business activities related to selling goods and services to final consumers.
} 
single directional retail sprawl change with higher or lower pace. This process has not resulted in shaping any real polycentric structure, since the city centre has retained its primary role and retail sprawl in LHE has proceeded rather evenly across all city fringes.

We believe that unlike de-concentration, sprawl should be measured by the density dynamics of a certain urban function (i.e. retail) within a certain territory (e.g. the LHEs) rather than by the comparative share of this very simple function in different zones of the city.

Stanilov has summarised the major positive and negative characteristics of post-socialist urban trends in CEE cities. Among the positive impacts, he includes the diversification of monofunctional areas, the revitalisation of some urban districts, increases in individual standards and choices, the diversification of market choices, the increase in shopping opportunities and personal mobility. We claim that all of these positive impacts could be attributed to the process which is the focus of our attention in this paper - the retail sprawl in socialist microrayon areas. With the same process, however, we can associate some features which Stanilov calls "negative": chaotic development patterns, the surge in illegal construction, the privatisation of the public realm, etc. (Stanilov, 2007a, p. 9). To some extent, retail sprawl might contribute to the problems of social stratification and increased congestion, as well as air and noise pollution. Even such a non-exhaustive list demonstrates the highly controversial impact that retail sprawl has had on the development of large-scale housing estates (LHE) and the post-socialist metropolis in general. Our approach prefers to demonstrate the outcomes of the spreading of non-residential functions (namely, retailing) to the peripheral socialist-era urban zones - which we call "retail sprawl"3.

\subsection{The concept of microrayon and its legacy}

Rooted in the ideas of Clarence Perry, Le Corbusier and other Western urbanists and adopted in the USSR, the microdistrict (microrayon $)^{4}$ concept became one of the main urban planning principles and spread into many communist countries in the form of strict construction norms and regulations. Over several decades, in many countries, it became impossible to build housing in the largest cities in any other form than a microdistrict. Due to such regulations, almost all new residential areas erected after the Second World War in postSoviet countries form huge massifs and similar-looking urban belts. Even today, residential areas in some countries are being built under the principles of the microrayon. This concept has survived several generations, in changes of political regimes and types of socio-economic relations.

The introduction of the microrayon concept was aimed at solving several problems at once:

- to fill in the gap of housing shortages in socialist cities recovering from the destructions of war and, at the same time, growing under industrial urbanisation processes;

- to do it as quickly and cheaply as possible;

- to serve the needs of growing industrial zones by concentrating the workforce in close vicinity to factories and institutions; and
- last but not least, to provide the Soviet working class with access to basic social and retail services (Fedchenko, 2012).

Implemented as an alternative to the "perimeter quarter" structure of an industrial city, the microrayon concept was used most appropriately to meet all of those challenges. Unlike "the perimeter quarter", a microdistrict was not shaped by blocking together perimeter structures of residential buildings with inner yards in the middle. Rather, it consisted of stand-alone linear bar-like buildings, in different orders filling the area between the roads (for a fuller understanding of the different types of microdistricts: see Meuser and Zadorin, 2016 or Dorofeev, 2014).

In its genesis, a "microdistrict" is similar to the American "neighbourhood", but it had inherent unique aspects from communist regimes (as a supplementary residential element to the major industrial and business zones of cities). According to uniform urban regulations throughout the USSR, the core of the microrayon planning principles aligned it with equal locational accessibility to major public and retail services. Thus, the rules from 1962 required that the microrayon should provide for its population an exhaustive set of public and retail services, namely: schools, kindergartens, retail trade, public catering, household services, social clubs, libraries, laundry services, garage spaces for personal vehicles, garbage disposal and parking grounds (SNIP, 1967). At later times, standards were further detailed and amended. For example, the 1989 rules provided that a microdistrict should average 10-60 hectares (but not exceeding 80) and should not be dissected by major streets and motorways (SNIP, 1994).

The main planning principle, however, remained - with restricting the physical accessibility to public and retail services - such that the location of these objects was the firm anchor which determined the allocation of all the surrounding housing. The same 1989 rules prescribed the allocation of all FMCG (Fast Moving Consumer Goods) deliveries (normally in the form of one supermarket, possibly combined with some repair or other service providers) not exceeding $500 \mathrm{~m}$ from any entrance door; with schools and kindergartens to be within 300-750 m, depending on the microdistrict type (SNIP, 1994). The same set of rules prescribed the allocation of facilities providing services of periodic and episodic demand. For example, sports centres - within $1,500 \mathrm{~m}$, post offices and banks within $500 \mathrm{~m}$, etc. Thus, a four-tiered spatial structure of services accessibility should have been developed: a small microdistrict quarter (hosting only a kindergarten); a larger microdistrict (hosting 1-2 schools, supermarket and everyday services); an even larger district (hosting for instance, a small department store, cinema etc.); and the largest macro district or city (hosting a major department store, theatre etc.) (Gorlov, 2014; SNIP, 1994).

For this research topic, it is very important to stress that under the Soviet centralised state- owned planned economy, no other businesses in no other locations could have emerged - apart from what was prescribed by the set of rules mentioned above. The uniformity of these rules throughout

\footnotetext{
${ }^{3}$ Unlike in many capitalist countries where peripheral ('sleeping') low-density communities tend to exclude the retail economy, post-Socialist LHEs distinctly produce a demand for local retail inclusion. Indirectly this is shown by public actions against the demolition of temporary retail facilities, followed by claims to replace them with new permanent ones. This particular topic is beyond our focus here but could be the subject of future study.

4 The Russian word "microrayon" is translated as microdistrict. Later we intend to use them as synonyms, using the transliteration of the Russian version rather to indicate the corresponding concept, and shall apply 'microdistricts' to its actual implication.
} 
the former USSR has produced vast uniform, almost monofunctional residential areas of microdistricts with the same trade and service spatial organisation. The presence and especially the physical extent of these microdistrict area types is one of the most visible distinctions of a postSoviet large city - from the Baltics to Central Asia (if not to say - from Albania to Siberia and the Russian Pacific coast: Murphy and Hourani, 2013, p. 24). A recent comparison of microdistricts in Eastern Europe and housing projects from the 1960s to the 1970s in Western Europe can be found in Monclus and Medina (2016).

\subsection{The contemporary stage of retail development: Changing functions of microrayons}

Several stages in retail spatial developments in Russian cities after socialism, using the case of St. Petersburg, have been outlined in Axenov et al. (2006) and Aksenov (2016). The first stages were attributed to what we called a 'process of spatial saturation with consumer goods and services'. These lasted until the end of the institutional transformation period at the beginning of the 2000 s, and were responsible for the development of tens of thousands of temporary trade outlets such as kiosks, tents, open-air markets and pavilions. The last post-transformational stages are of crucial importance primarily for understanding the role of retail in changing the urban functions of microdistricts areas. Therefore they require some elaboration.

The stage which preceded the current situation was most pronounced from 2002 to 2007. It was the stage of the dominance of hypermarkets and large chain retailers. In 2007 in St. Petersburg, 66\% of all purchases were made in hypermarkets, malls or from chain retailers (Bolshoi Server Nedvizhimosti, 2008). Unlike the situation in some Western cities, hypermarkets and malls occupied locations not only near motorways at the city's edge but rather near major public transportation nodes in the microdistrict areas. Kiosks, markets and pavilions which prevailed in retail spending in the previous stages (60\% of purchases in St. Petersburg in 1997), retreated but were present primarily in the form of illegal stalls and tents (Komsomolskaya Pravda - Sankt-Peterburg, 1997).

During the last decade, shopping behaviour has changed dramatically again. In the present stage (2008-2016), instead of going for FMCG shopping in a hypermarket once a week by car, the majority of city dwellers started to prefer shopping 2-3 times a week in smaller shops located within walking distance from their home. Although the amount spent in the large retailers remained very high, many of them switched to a chain convenience store format to meet the new demand. Small- and medium-sized businesses contributed to this trend as well, which included, inter alia, bringing the popular "shop-in-shop" retail format into existence. The majority of such convenience type establishments flooded formerly monofunctional residential microdistrict areas. Thousands of them were built in the former flats on the ground floors of the Soviet era residential apartment blocks. Kiosk type set-ups moved from the transportation nodes deeper into the residential quarters as well (Aksenov, 2016) ${ }^{5}$.

We believe that these stages are not unique to St. Petersburg, but rather represent some universal processes going on almost concurrently in CEE cities. For the capitals of the Baltic states, similar processes were described in Standl $(1999,2002)$ and especially for Vilnius in Standl (2003). In an already-cited publication, Stanilov (2007b, p. 89) described several stages of retail development on the outskirts of CEE cities which look quite similar to those described above. For example, he identified the early trend of filling in the Soviet-era neighbourhoods with smallscale commercial activities in the 1990s, as a "survival strategy". The second phase, attributed by Stanilov to the late 1990 s through the early 2000 s, he described as the largescale, primarily foreign investments coming to the CEE urban retail market and inserting macro-establishments on the outskirts. This is obviously the stage mentioned above which was pronounced in St. Petersburg somewhat later during 2002-2007. Stanilov also outlined the beginning of a new stage based on the growing importance of next-door retail facilities (Stanilov, 2007b, p. 90). This is the latest phase which we have described as well, and it is the focus of our research interests here.

\section{Methods and data}

\subsection{Research objectives}

Studies of the origin and mechanisms of post-socialist urban change have resulted in the implementation of several theoretical and methodological approaches (see, for example, Sýkora, 2009; Sýkora and Bouzarovski, 2012; Hamilton et al., 2005; Tsenkova and Nedovic-Budic, 2006; Borén and Gentile, 2007; Stanilov, 2007a). One of the most general discussions on the outcomes of post-socialist transformation in general and on urban development in particular, has led to a virtual crystallisation of two development trajectories, which may be mutually contained or mutually exclusive. The first one tends to treat post-socialist transformation as a sort of 'catching-up' development to the more or less uniform modernisation trend (universalism). According to the second trajectory, the extent of the specificity of post-socialist legacies leads to valued different outcomes from that of the "global" modernisation trends, which are not uniform in different post-socialist societies (uniqueness). For in-depth discussions of this discourse in post-socialist urban studies, see for example Stryjakiewicz et al. (2008), Wiest (2012) and Bernt (2016).

Thus, our more general objective has the goal of contributing to this discussion. Regarding our topic, several points make this contribution potentially highly controversial. First, we are focused on the processes of restructuring one of the most specific Soviet urban legacies - vast microdistrict areas. Second, the specific retail developments in the former socialist urban outskirts may lie not only with the specific architectural material structure of microdistricts, but with the strikingly different (from that in the West) starting point - the severe shortages in the Soviet period of retail supplies and retail delivery locations. So, on the one hand, we have vivid specificity both of the research object (socialist microdistricts) and the subject (post-Soviet retail market saturation). But, on the other hand, urban retail sprawl is a quite general process which is experienced by many cities in the world. Moreover, market-driven city economies have quite common rules which dictate certain requisites for retail urban spatial development. So, what is the result of simultaneously combining the unique and the universal in retail sprawl in post-Soviet microdistricts?

\footnotetext{
${ }^{5}$ For visualisation of this process see Axenov, 2017.
} 
We believe that one of the possible ways to answer this question is to compare examples of post-Soviet cities which have passed through quite different "paths" during the last 25 years. If the results of such a comparison turn out to be more different than similar, we might then conceptualise them as showing the prevalence of path-dependency; if not, then the universalists could possibly add this evidence to their arguments.

To accomplish this task we had to choose cases which:

- had a comparable starting position, i.e. being Soviet cities hosting all major types of microdistricts built in the period late $1950-1980 \mathrm{~s}$;

- preferably ranked highly in the Soviet hierarchy of its retail distribution system and hence were among the leaders in Soviet urban retail development; and

- have passed through the most contrasting "paths" after socialism.

With no doubt, one developmental extreme in such "paths" could be found among the major cities of the three Baltic EU member states which were former members of the USSR. The largest city and at the same time the present leader in retail development among the three Baltic states is Vilnius, the capital city of Lithuania. A contrasting developmental "path" may be found in one of the major Russian cities which experienced quite different economic and political regulation during the post-socialist period. Among Russian metropolitan areas, Leningrad - St. Petersburg has now become the leader in retail development, while during Soviet times it was at the same rank as Vilnius in the Soviet centralised retail supply distribution system (for details, see Aksenov, 2016). At the same time, both Vilnius and St. Petersburg might represent universalist trends in retail and urban development in the Baltic states and Russia respectively (see Standl, 2003; Axenov, 2017). The presence of research expertise on both of the abovementioned cities became the last but not the least, factor for choosing Vilnius and St. Petersburg as research case studies for this comparison. The present study thus focuses on comparative parameters of the retail sprawl process in contrasting post-socialist cities. The forces that shaped the retail development and its landscape are discussed further in Aksenov (2016), Axenov (2017), Axenov et al. (2006).

\subsection{Field study and data}

For the analysis of retail sprawl, we used data for both cities for the years 1987-1989 (for Vilnius and St. Petersburg, respectively), i.e. the last years of the socialist economy, and 2016. Data on the territorial structure of trade in the period 1987-1989 were retrieved from the respective telephone books of Vilnius and St. Petersburg (Leningrad, at that time) and mapped. In order to assess current conditions, we carried out a field study in June 2016. Geography students of St. Petersburg State University and Vilnius University were involved in data collection. For the field work, we selected a comparable 18 research case study areas in St. Petersburg and 18 in Vilnius. For proper comparison, all 18 research areas in St. Petersburg were chosen within a centre-periphery segment, with generally the same population and comparable morphology to Vilnius as a whole. St. Petersburg has a radial-ring structure and for the 500K-resident segment (Vyborgsky rayon) that was chosen, it stretched from the centre to the north of the city with all types of residential buildings represented. Vyborgsky rayon has a unified transportation system for connection with the centre of the city (one metro line) and is morphologically separated from the other parts of the city. So, we based our research on comparable populations (500K) and number of case polygons (18).

The area of the 36 polygons was mapped. All street format (small size; separate deliveries) commercial objects ${ }^{6}$ were photographed and classified according to several criteria including types of demand, e.g. daily, periodic and episodic. The latter classification was used by Soviet planners and underlies the actual allocation of deliveries at the starting point of the period we studied. The actual frequency of visits today to objects was investigated by Aksenov (2016), who confirmed the possibility of separating not only goods but also types of retail objects according to the frequency of demand. For the purposes of this study, we used the classification of retail objects according to the primary type of product in the assortment. A special sociological survey was not conducted, and the division by types of demand was carried out on the basis of the authors' expert assessments of the potential frequency of demand (relevance) for a particular type of goods (services). All forms of mobile commerce were also mapped: pavilions, kiosks, van shops, tents/covered trays, as well as trays/ sellers without tray. All of this information provided the basis for further analysis. Figure 1 illustrates the current morphology of two sample locations.

\section{Results: Comparative dynamics of retail sprawl}

The results of our survey reveal several important and quite unexpected facts (see Tab. 1). Firstly, the overall number of different retail and "street format" B2B (business to business) branches in microdistrict areas in 2016 was unexpectedly high - more than 50 in each city, which by several times exceeds that of the period 19871989. Such numbers obviously indicate the emergence in former socialist "sleeping quarters", of a highly diversified retail economy covering the majority of retail demand types (see Fig. 2, below). The number of business facilities increased almost 20 -fold in St. Petersburg and by at least several times in Vilnius. All of this indicates strongly the saturation of formerly almost exclusively monofunctional residential urban areas, with the new commercial functions. Secondly, and an even more unexpected fact the structure of retail branches in the two post-Soviet cities according to the type of demand (i.e. daily-periodicepisodic) in 2016 was almost identical. Since our research case study areas have developed in different countries and under different political-economic paradigms, for a quarter of a century, this must indicate some commonality for the post-Soviet space character of such urban trends. Third, in both cases, the retail activity serving periodic and episodic demand in 2016 by far outnumbered FMCG retailing - both by the variety of branches (which is quite understandable) and by the number of facilities. The last important and not so obvious fact is that in 2016 there was a widespread use of mobile retail facilities of different locational and constructive types in both cities. The extent of this phenomenon obviously relates to the legacy of postsocialist transformation and shows some of the specificity of post-Soviet urban development. Since the scale of trade

${ }^{6}$ We also mapped street format B2B (business to business) facilities because they compete for the same locations and real estate with retail. 


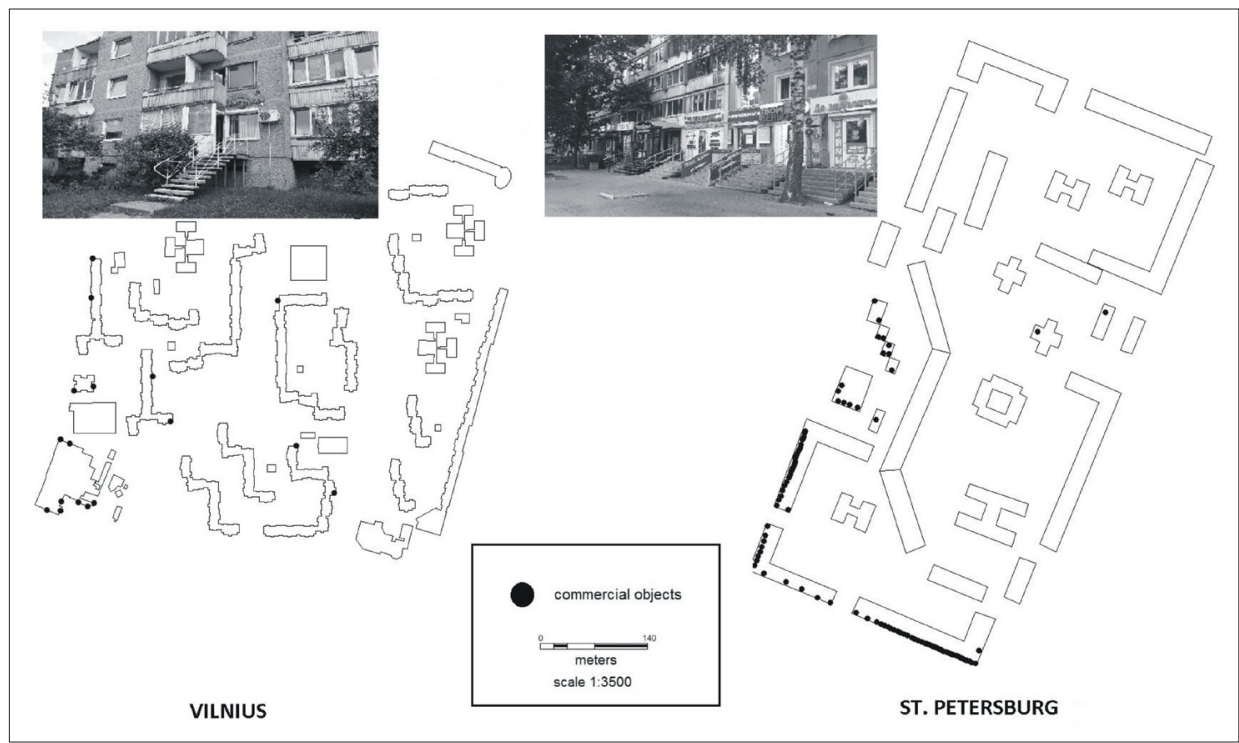

Fig. 1: Samples of one of the research case study areas in each city (microdistrict quarters) Source: authors' 2016 survey

\begin{tabular}{|c|c|c|c|c|c|c|c|c|}
\hline \multirow[t]{2}{*}{ Type of facilities } & \multicolumn{2}{|c|}{ St. Petersburg, 1989} & \multicolumn{2}{|c|}{ St. Petersburg, 2016} & \multicolumn{2}{|c|}{$\begin{array}{c}\text { Vilnius, } 1987 \\
\text { [5 most comparable }^{\text {polygons }^{\mathrm{c}}}\end{array}$} & \multicolumn{2}{|c|}{$\begin{array}{c}\text { Vilnius, } 2016 \\
\text { [all polygons] }\end{array}$} \\
\hline & branches & facilities & branches & facilities & branches & facilities & branches & facilities \\
\hline Permanent, B2C, daily demand & 2 & 28 & 7 & 305 & 2 & 4 & 7 & 9 \\
\hline Permanent, B2C, periodic demand & 8 & 34 & 25 & 663 & 12 & 13 & 24 & 227 \\
\hline Permanent, B2C, episodic demand & 3 & 4 & 20 & 130 & 0 & 0 & 16 & 74 \\
\hline Permanent, mixed or $\mathrm{n} / \mathrm{a}^{\mathrm{a}}$ & 0 & 0 & $\mathrm{n} / \mathrm{a}$ & 97 & 0 & 0 & $\mathrm{n} / \mathrm{a}$ & 39 \\
\hline Permanent, B2B ${ }^{\mathrm{b}}$ & 0 & 0 & 8 & 46 & 0 & 0 & 7 & 30 \\
\hline Permanent: Total & 13 & 66 & 60 & 1,241 & 14 & 17 & 54 & 439 \\
\hline Mobile retail facilities, incl. & $\mathrm{n} / \mathrm{a}$ & $\mathrm{n} / \mathrm{a}$ & $\mathrm{n} / \mathrm{a}$ & 341 & 1 & 1 & $\mathrm{n} / \mathrm{a}$ & 80 \\
\hline Standing alone & $\mathrm{n} / \mathrm{a}$ & $\mathrm{n} / \mathrm{a}$ & $\mathrm{n} / \mathrm{a}$ & 228 & 1 & 1 & $\mathrm{n} / \mathrm{a}$ & 62 \\
\hline Within agglomerations & $\mathrm{n} / \mathrm{a}$ & $\mathrm{n} / \mathrm{a}$ & $\mathrm{n} / \mathrm{a}$ & 113 & 0 & 0 & $\mathrm{n} / \mathrm{a}$ & 18 \\
\hline Permanent and mobile: Total & $\mathbf{n} / \mathbf{a}$ & $\mathbf{n} / \mathbf{a}$ & $\mathbf{n} / \mathbf{a}$ & 1,582 & 15 & 18 & $\mathbf{n} / \mathbf{a}$ & 519 \\
\hline
\end{tabular}

Tab. 1: Retail structure in microdistricts of St. Petersburg and Vilnius during Soviet times and the present (for 36 case study areas). Source of data: St.Petersburg 1989 and Vilnius 1987 -authors' calculations on the basis of respective phone books data; St.Petersburg 2016 and Vilnius 2016 - data based on the authors' field research

Notes: ${ }^{a}$ mixed or $n / a$ - predominantly facilities exposed for sale/rent or shop-in-shop type facilities; ${ }^{b}$ only "street format" B2B facilities were registered, i.e. small size, with their own entrance from the street; ${ }^{c}$ These polygons experienced minimal intrusion of post-socialist residential development, like all the studied areas in St. Petersburg, and hence we consider them as the most comparable ones between the two cities. In all the rest of the study areas in Vilnius, much of the housing has been built after 1991. But since the morphology of these polygons is very similar to socialist era microdistricts, we considered it appropriate to include them in the comparison.

in mobile retail facilities all over the post-Soviet territory compared to Western cities, is incomparably high (see for example, Axenov et al., 2006; Axenov, 2017), we tend to treat it as an important and uniform indicator of a pathdependency trend.

Since retail facilities serving all types of demand are represented in contemporary microdistricts, one may conclude that they should look for clientele at different spatial scales: some branches (e.g. next-door grocery stores) target clients from one quarter only, others (e.g. cafes) from several quarters (i.e a microdistrict), a district (e.g. department stores) or, possibly, even several districts (e.g. concert halls). The locational priorities of such different branches cannot help but differ, specifically the locational preferences of B2B facilities. As already indicated, we registered only "street format" offices, which competed with B2C (business to consumer) retail establishments for location. In comparison with the city in general, the number of B2B branches in microrayon areas was rather limited: 7-8 in the studied cities.

So, what branches in business services tend to choose such locations and what are their objectives in such a choice? The global post-industrial trend of dispersal of office activity from city centres could obviously not be the main reason for the emergence of only a few small size "street format" offices in the former "sleeping" quarters of Soviet microrayons. Such global trends rather contribute to the dispersal of larger office centres serving businesses which are basically 

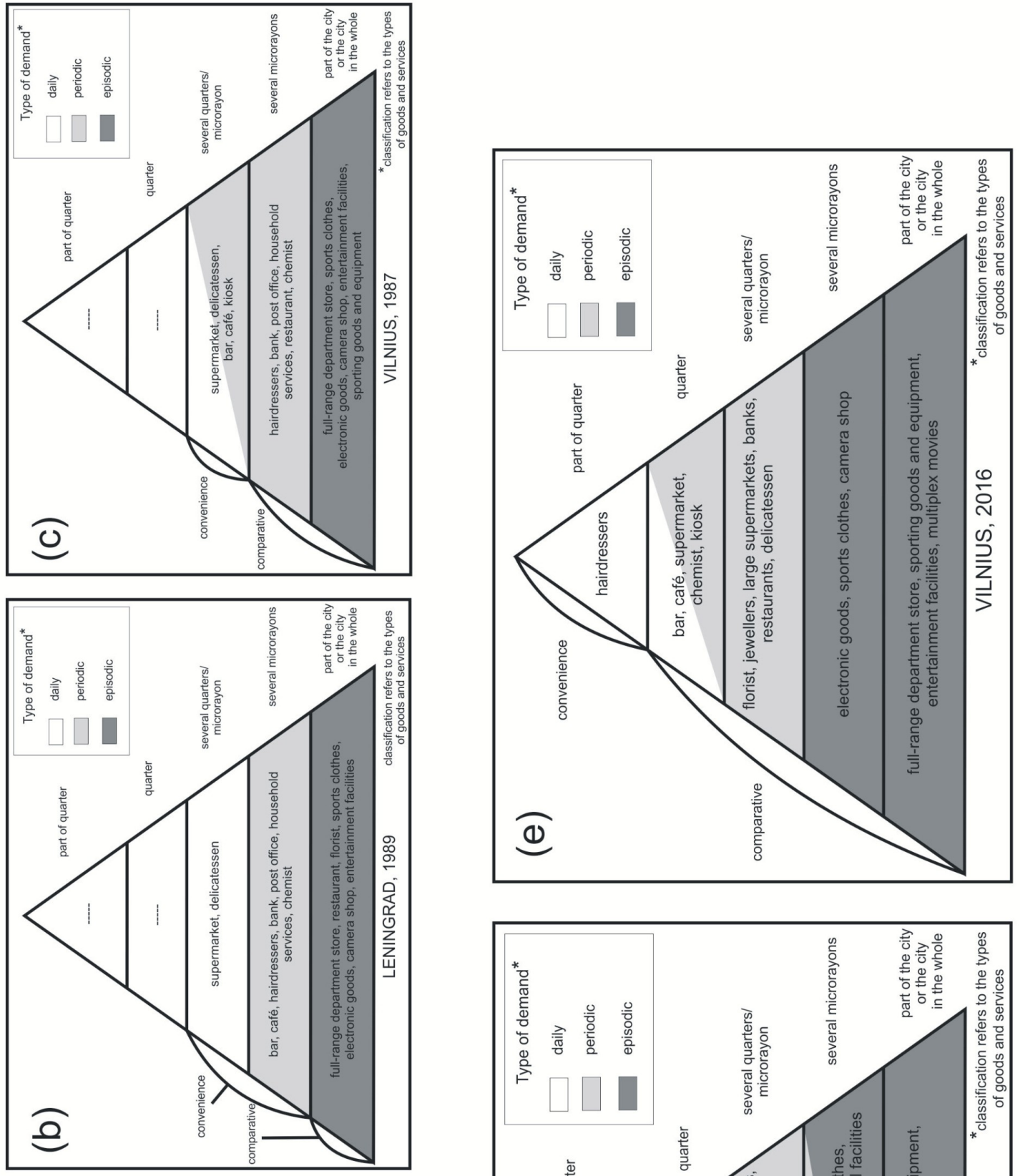

$\frac{0}{3}$
$\frac{\pi}{3}$
0
0
0
0

วิ

ป

$\ddot{2}$

竎

$\frac{2}{2}$

ही

శై

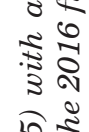

$\sqrt{2} \frac{2}{2}$

s.

की

ปี

है

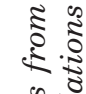

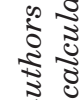

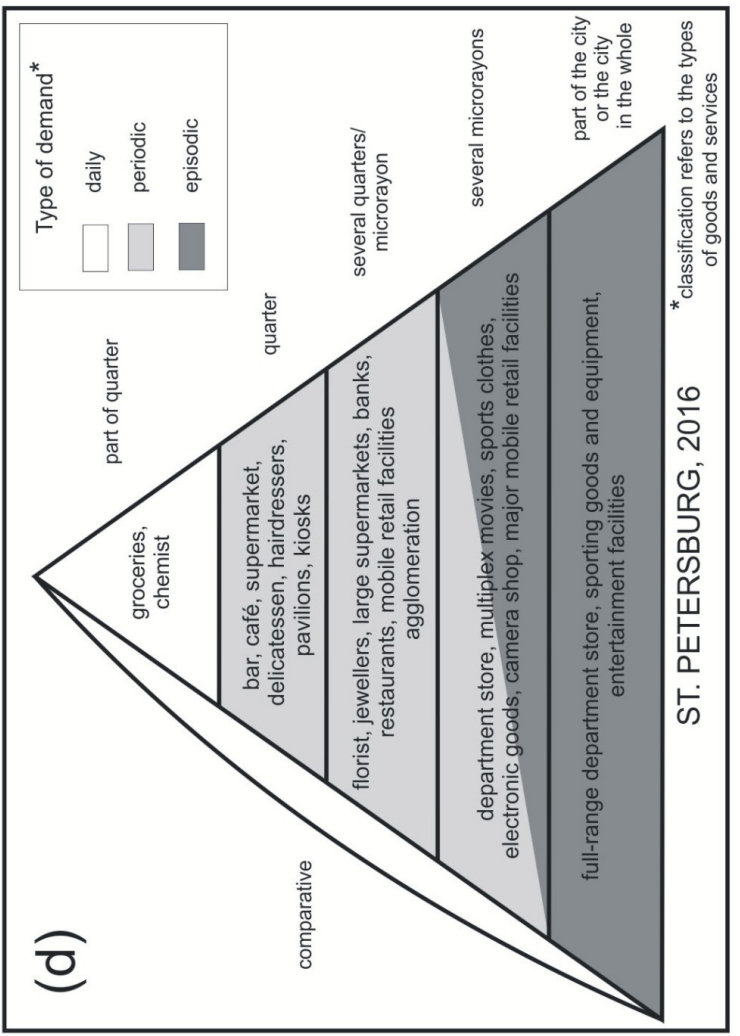

ำ

उे స్

원

है

ชิ

这

ปั

స్తి

.ำ

ปิ

ह.

4 ญे

సे ฏू

¿.

๑ 8

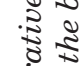

:

हิ

iv $\frac{\widetilde{J}}{\widetilde{J}}$

$\infty_{0} \frac{0}{0}$ 
indifferent to micro-location within a certain city and whose clientele is located in the broader markets. The composition of B2B branches represented by the small facilities in our case study research areas indicates that they rather target customers out of local business, and they offer the most needed business services to emerging businesses. Most B2B facilities cannot serve big businesses very effectively ${ }^{7}$. If this is true and local B2B activity here targets primarily the newly-emerged local retail business customers, then it means that the extent of these local retail operations is substantial enough for the survival of B2B services.

Several conclusions can be made thus far. First, we may state that the microrayon principle of retail organisation in former microdistricts has been completely destroyed by the introduction of market forces. Second, the residential (plus social services) monofunctionality of these urban areas has been broken by the intrusion of numerous retail activities. Third, this retail activity includes far more than the local FMCG provisions, including a vast range of branches of periodic and even episodic demand which formerly had been located almost exclusively in the city centre (for 1989 data: see for example Axenov et al., 2006). Fourth, the scale of retail activity in Soviet microdistricts became so extensive that it contributed to the redistribution of functions within the urban area in general, not only dispersing retail activity to the outskirts, but even taking away B2B functions from the city centre and thus breaking down its exclusivity there as well.

During the final days of socialism in the USSR, considered as the starting point for our analysis, Yeates (1990, p. 245) outlined the principles of retail facilities allocation in the North American city using a simple graph (see Fig. 2a). For comparison, we took Yeates' model and applied it to both of our cases, first trying to show the state of retail development in Soviet St. Petersburg's (Leningrad's at that time) and Vilnius' microdistricts in the late 1980s, and then versus what it is today. In Figures $2 a-2 e$, we have purposely depicted only those types of facilities which were used by Yeates (1990), adding to them a few of those which we consider indicative and specific for our cases, attributing them to the respective scale where they were pronounced.

As this comparison shows, by the end of socialism in 1990, the retail distribution patterns both in Leningrad's and Vilnius' microdistricts had very pronounced differences to those of a typical North-American city. In comparison with Yeates' model, the upper hierarchical levels were not served by any retail facilities at all in both Soviet cities. This means at minimum that daily goods and services deliveries in Soviet-era microdistricts were much less numerous and were much sparser than that in a typical North American city. Comparison shopping started at much longer distances from the consumer's home as well. Considering the presumably higher population densities in Soviet microdistricts, this difference looks even more striking.

By 2016 the patterns in post-Soviet microdistricts have changed dramatically. They began to match the Yeates pattern almost entirely. Any differences between St. Petersburg and Vilnius became almost absent as well. The differences between the contemporary retail spatial organisation in the microdistricts of the two post-Soviet cities and the 25 years- old North American pattern resulted primarily from morphology - in the physical structures used for retail activities. Apart from the previously-mentioned former ground floor flats refurbished for retail use (especially in St. Petersburg), both post-socialist cities' microdistricts hosted numerous mobile facilities of different sorts (see Tab. 1). Urban morphology contributed to differences in density and allocation principles of retail facilities in the microdistricts built in different times and under different morphological and architectural standards. So, in the first microdistricts built in the period from the late 1950s to the early 1960s, the density of retail facilities is the lowest among all types of microdictricts ${ }^{8}$. Their morphology is less accommodating to retail development due to minimal pedestrian and automobile logistics within these quarters.

\section{Conclusions}

Our findings on retail and street format business development in post-Soviet St. Petersburg and Vilnius confirm that this process resembles what is normally described as retail sprawl. If we use the description of this term mentioned at the beginning of the paper, we can state that in both cities, microdistrict areas experienced a primarily centrifugal process of spatial expansion of retail and street format business into the areas formerly almost totally unoccupied by them. The number of business facilities there grew by up to 20 times, with the number of branches growing by an order of 5 . The process of retail sprawl covered the peripheral zones of the two cities where microdistricts are located. A very slow rate of suburbanisation (especially in the case of St. Petersburg) makes vast microdistrict areas even more "peripheral". Retail sprawl as used here related to one specific urban function, namely commercial businesses. Residential functions expanded in these areas almost independently during Soviet times, and only decades later did commercial functions flood them. This process has reduced some commercial functions in the urban core as the majority of branches which are spread to the microdistricts today, were formerly represented only in the city centre. The spatial patterns of such branches are much more sparse at the urban fringes (Axenov et al., 2006). Retail sprawl was a market-driven process and to a certain extent, spontaneous. The best evidence for this statement lies in the fact that the result of this process indicated that structurally and locationally the patterns were almost identical in these two cities, which for a quarter of a century had developed under different political and economic paradigms.

This leads to the conclusion that the term "retail sprawl" does accurately describe one of the important processes which have reshaped the former socialist microdistricts. As hypothesised at the outset, the social (and urban) consequences of this type of sprawl are obviously not only negative. In fact, the changed structure of these formerly monofunctional areas has made them functionally very close to the urban core, including them into the intraurban circulation of goods and capital, redirecting flows and making the city centre's service burden much lighter. They have started to contribute to the city economy, shaping new labour, commercial and locational markets which did not exist before.

\footnotetext{
${ }^{7}$ Among B2B branches, we registered services in investment and finance, legal and marketing services, corporate identity and branding, brokerage, security and guards, office and business equipment trade.

${ }^{8}$ This trend is more pronounced in St. Petersburg where microdistricts built in different periods are territorially separated, as opposed to more mixed in the construction composition of microdistricts in Vilnius.
} 
The results of our study also provide a controversial contribution to the on-going discussion on universalism vs. uniqueness in post-socialist urban development. On the one hand, the conclusion seems quite clear. We have compared the two contrasting post-socialist "paths" of St. Petersburg and Vilnius, and the results show basically the same patterns shaped by the processes studied. This means that, irrespective of regulation differences and other "pathdependent" impacts, the result was generally identical. Additionally, we have studied the development of universal market processes on rather unique post-Soviet research areas, that of vast microdistrict urban areas. We compared our results with a 25-year old model North American case and found almost total verification for both of our cases. This cannot help but provide supporting evidence to universalists and for those proponents of the 'catching-up' approach to post-socialist urban studies.

On the other hand, we also found some very pronounced differences to international patterns in morphological outcomes - urban forms and physical structures there were quite different from other cities in the world. These features concern the presence of numerous mobile facilities and their agglomerations, as well as specific forms of conversion of former residential real estate properties into commercial ones.

\section{References:}

AKSENOV, K. (2016): Evolution of the types of shopping and spatial organization of retail trade in the postSoviet metropolis. Regional Research of Russia, 6(4): 375-386.

AXENOV, K. (2017): Retail, Services and Leisure, In: Brade, I., Neugebauer, C. [eds.]: Urban Eurasia: Cities in Transformation (pp. 208-223). Berlin, DOM Publishers.

AXENOV, K., BRADE, I., BONDARCHUK, E. (2006): Transformation of Urban Space in Post-Soviet Russia. London, New York, Routledge.

BERNT, M. (2016): How post-socialist is gentrification? Observations in East Berlin and Saint Petersburg. Eurasian Geography and Economics, 57(4-5): 1-23.

BOLSHOI SERVER NEDVIZHIMOSTI (2008): Torgovaya nedvizhimost' Peterburga: itogi razvitiya za 1 kvartal 2008 goda [online]. [cit. 30.03.2017]. Available at: https://www.bsn.ru/analytics/commercial_ real_estate/spb/3710_obzor_rynka_kommercheskoy_ nedvizhimosti_sanktpeterburga_za_3_mesyaca/

BOREN, T., GENTILE, M. (2007): Metropolitan processes in post-communist states: an introduction. Geografiska Annaler, B 89(2): 95-110.

BRUEGMANN, R. (2005): Sprawl: a compact history. Chicago, the University of Chicago Press.

COUCH, C., LEONTIDOU, L., PETSCHEL-HELD, G. (2007): Urban Sprawl in Europe. Landscapes, Land-Use and Policy. Wiley-Blackwell.

DAWSON, J.A., LORD, J. D. (2013): Shopping Centre Development: Policies and Prospects. In: McAnnaly, P. [ed.]: The Economics of the Distributive Trades. Vol. 10 (pp. 9-39). Routledge.

DOROFEEV, P. (2014): Neighborhood structures of the 1960s-1970s in Irkutsk. Journal of architecture, design and urbanism, 39-40: 230-251.
EUROPEAN ENVIRONMENT AGENCY (2006): Urban sprawl in Europe - The ignored challenge. Report No. 10/2006. Copenhagen.

FEDCHENKO, I. (2012): Humanistic Idea of a Microdistrict in the XX. Century. Journal of Siberian Federal University. Humanities \& Social Science, 5(5): 707-718.

GORLOV, V. (2014): Novie Cheremushki. Transition to mass introduction into the microdistrict system in the USSR in 50-60s of XX century. Bulletin of the Moscow Regional State University. Series: History and Political Sciences, 2: 61-68.

GU, C., WEI, Y. D., COOK, I. G. (2015): Planning Beijing: socialist city, transitional city, and global city. Urban Geography, 36(6): 905-926.

HAMILTON, F. E. I., DIMITROWSKA-ANDREWS, K., PICHLER-MILANOVIC， N. (2005): Transformation of Cities in Central and Eastern Europe: Towards Globalisation. Tokyo, United Nations University Press.

KENT, T., OMAR, O. (2003): Retailing. New York, Palgrave Macmillan.

KOMSOMOLSKAYA PRAVDA - St.Peterburg, 11 April, 1997.

MAKSIC, M. (2016): Institutional obstacles in large-scale retail developments in the post-socialist period - A case study of Niš, Serbia. Cities, 55: 113-121.

MEUSER, P., ZADORIN, D. (2016): Towards a Typology of Soviet Mass Housing: Prefabrication in the USSR, 1955-1991. Berlin, DOM Publishers.

MONCLUS, J., MEDINA, C. D. (2016): Modernist housing estates in European cities of the Western and Eastern Blocs. Planning Perspectives, 31(4): 533-562.

MURPHY, E., HOURANI, N.B. (2013): The Housing Question: Tensions, Continuities, and Contingencies in the Modern City. Routledge.

MUSIL, J. (1993): Changing urban systems in postcommunist societies in Central Europe: analysis and prediction. Urban Studies, 30(6): 899-905.

NAGY, E. (2001): Winners and losers in the transformation of city centre retailing in East Central Europe. European Urban and Regional Studies, 8(4): 340-348.

NILSSON, K., PAULEIT, S., BELL, S. et al. (2013): Periurban futures: Scenarios and models for land use change in Europe. Berlin-Heidelberg, Springer-Verlag.

OUESLATI, W., ALVANIDES, S., GARROD G. (2015): Determinants of urban sprawl in European cities. Urban Studies, 52(9): 1594-1614.

RUDOLPH, R. (2001): Stadtzentren russischer Großstädte in der Transformation - St. Petersburg und Jekaterinburg. Beiträge zur Regionalen Geographie, 54.

POJANI, D. (2011): Urban and suburban retail development in Albania's capital after socialism. Land Use Policy, 28(4): 836-845.

SARZYNSKI, A., GALSTER, G., STACK, L. (2014): Typologies of sprawl: investigating United States metropolitan land use patterns. Urban Geography, 35(1): 48-70.

SIMION, G., NISTOR, C. (2012): Spatial structure changes inside post-communist capital city of Bucharest. Human Geographies - Journal of Studies and Research in Human Geography, 6(1): 79-89. 
SNIP 2.07.01-89 (1994): Gradostroitel'stvo. Planirovka i zastroika gorodskikh i sel'skikh poselenii.

SNIP II-K.2-62 (1967): Planirovka, zastroikai blagoustroistvo.

STANDL, H. (1999): Post-sozialistischer Wande innerstädtischer Einzelhandelsstrukturen im Baltikum. Der Transformationsprozess und seine Determinanten, dargestellt am Beispiel der drei Hauptstädte Tallinn (Estland), Riga (Lettland) und Vilnius (Litauen). Bamberg, Otto-Friedrich-Universität.

STANDL, H. (2002): Divergenzen und Konvergenzen in der post-sozialistischen Entwicklung der drei baltischen Hauptstädte (Tallinn, Riga und Vilnius). Geographie und Schule, 136(24): 15-23.

STANDL, H. (2003): Vilnius' long way in forming a modern city-centre. Geografija, 39(1): 46-54.

STANILOV, K. (2007a): Taking Stock of Post-Socialist Urban Development: A Recapitulation. In: Stanilov, K. [ed.]: The Post Socialist City: Urban Form and Space Transformations In: Central and Eastern Europe after Socialism (pp. 3-17). Springer.

STANILOV, K. (2007b): The Restructuring of NonResidential Uses in the Post-Socialist. In: Stanilov, K. [ed.]: The Post Socialist City: Urban Form and Space Transformations in Central and Eastern Europe after Socialism (pp. 73-99). Springer.

STORPER, M., SCOTT, A. J. (2016): Current debates in urban theory: A critical assessment. Urban studies, 53(6): 1114-1136.

STRYJAKIEWICZ, T., BURDAK, J., ENEDY, T. (2008): Institutional Change and New Development Paths: Budapest, Leipzig, Poznan, Riga and Sofia. In: Musterd, S., Murie, A. [eds.]: Making Competitive Cities (pp. 93-112). Willey-Blackwell.
SYKORA, L. (2009): Post-socialist cities. In: Kitchin, R., Thrift, N. [eds.]: International Encyclopedia of Human Geography 8 (pp. 387-395). Oxford, Elsevier.

SYKORA, L., BOUZAROVSKI, S. (2012): Multiple Transformations: Conceptualizing the Postcommunist Urban Transition. Urban Studies, 49(1): 43-60.

SZAFRANSKA，E. (2013): Large housing estates in post-socialist Poland as a housing policy challenge. European spatial research and policy, 20(1): 119-121.

TSENKOVA, S., NEDOVIC-BUDIC., Z. (2006): The Urban Mosaic of Post-socialist Europe: Space, Institutions and Policy. Heidelberg, Physica-Verlag.

TUVIKENE, T. (2016): Strategies for comparative urbanism: post-socialism as a de-territorialized concept. International Journal of Urban and Regional Research, 40(1): 132-146.

VAN KEMPEN, R., DEKKER, K., HALL, S. et al. (2005): Restructuring large housing estates in Europe. Restructuring and resistance inside the welfare industry. Policy Press at the University of Bristol.

WASSENBERG, F. (2013): Large Housing Estates: Ideas, Rise, Fall and Recovery. Delft University Press.

WIEST, K. (2012): Comparative Debates in Post-Socialist Urban Studies. Urban Geography, 33(6): 829-849.

YEATES, M. (1990): The North American City. New York, Harper \& Row.

\section{Please cite this article as:}

AXENOV, K., KRUPICKAITĖ, D., MORACHEVSKAYA, K., ZINOVYEV, A. (2018): Retail sprawl in post-Soviet urban residential communities: Case studies of Saint-Petersburg and Vilnius. Moravian Geographical Reports, 26(3): 210-219. Doi: 10.2478/mgr-2018-0017. 